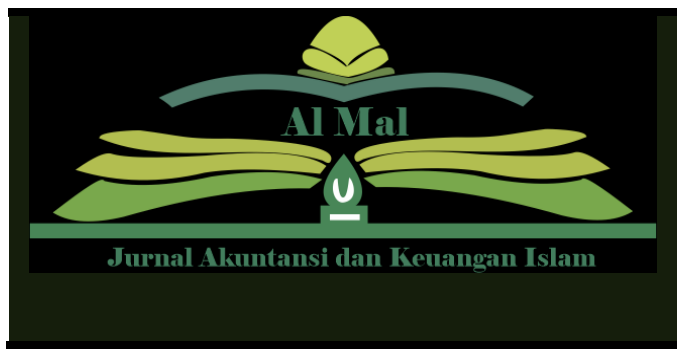

Al-Mal: JurnalAkuntansi dan Keuangan Islam E-ISSN: 2715-9477, P-ISSN: 2751-954X Volume 02 Issue 01, 21 Januari 2021 Journal Page is available to:

\title{
Implementasi Corporate Social Responsibility Terhadap Indeks Pembangunan Manusia yang Dimediasi Pertumbuhan Ekonomi Di Kabupaten Siak Riau
}

\author{
Budi Indrawati ${ }^{*}$, Murti Wijayanti ${ }^{2}$
}

$\mathbf{1}^{*}, \mathbf{2 , 3}$ Departement of Economics, Faculty Accounting, Universitas Bhayangkara Jakarta Raya, Indonesia

\begin{tabular}{l}
\hline \multicolumn{1}{c}{ ARTICLE INFO } \\
\hline Article history: \\
Received 11-06-2020 \\
Revised 14-06-2020 \\
Accepted 08-07-2020 \\
Available 21-07-2020 \\
Revised (1) 07-07-2022 \\
Revised (2) 17-07-2022 \\
Accepted 18-07-2022 \\
Revised Available 30-07-2022 \\
Kata Kunci: \\
Tanggung Jawab Sosial Perusahaan, \\
Indeks Pembangunan Manusia, \\
Pertumbuhan Ekonomi, \\
Pembangunan Berkelanjutan \\
\hline
\end{tabular}

Paper type: Research paper

Please cite this article: Indrawati, B., Wijayanti, M., \& Wati, R. "Implementasi Corporate Social Respon Terhadap Indeks Pembangunan Manusia yang Dimediasi Pertumbuhan Ekonomi Di Kabupaten Siak Riau" Al-Mal: Jurnal Akuntansi dan Keuangan Islam [ONLINE], Volume 02 Number 01 (Januari 21, 2021)

\section{Cite this document:}

Al-Mal 2th edition

\section{*Corresponding author} e-mail:

budi.indrawati@dsn.ubharajay.ac.id

Page: 23-47

ABSTRAK
Tujuan penelitian ini dilakukan untuk mengetahui
dampak CSR terhadap indeks human capital melalui
pertumbuhan ekonomi sebagai variabel intervensi
terhadap Kabupaten Siak Riau. Metode pendekatan
pada penelitian ini yaitu metode kuantitatif,
dengan alat olah data yaitu SPSS. Hasil penelitian
menunjukkan bahwa variabel CSR sebagian
memiliki pengaruh positif dan signifikan terhadap
indeks pembangunan manusia di Kabupaten Siak
Riau, sebagian CSR tidak memiliki pengaruh
signifikan dan negatif terhadap pertumbuhan
ekonomi di Kabupaten Siak Riau, dan sebagian
variabel pertumbuhan ekonomi memiliki pengaruh
positif dan signifikan terhadap indeks
pembangunan manusia di Kabupaten Siak Riau
Periode 2013 - 2017. Keterabatsan pada penelitian
ini terelatak pada penggunaan variabel penelitian
menggunakan CSR sebagai pengaruh indeks
pembangunan manusia yang dimediasi oleh
pertumbuhan ekonomi serta objek pengamatan,
sehingga memberikan peluang bagi peneliti-
peneliti yang lainnya untuk melakukan penelitian
dengan tema yang sama dan menambahkan
varaibel yang lain serta objek yang lebih luas.
Implikasi penelitian ini yaitu penerapan CSR
mempunyai peranan yang sangat penting dalam
indeks pembangunan manusia, dimana ketika
penerapan CSR sesuai dengan aturan perundang-
undangan, akan membawa dampak yang positif
diberbagai bidang seperti pertumbuhan ekonomi
dan lainnya.




\begin{abstract}
The purpose of this study was to determine the impact of CSR on the human capital index through economic growth as an intervention variable in Siak Riau Regency. The approach method in this research is quantitative method, with data processing tool, namely SPSS. The results showed that some CSR variables had a positive and significant effect on the human development index in Siak Riau Regency, some CSR did not have a significant and negative effect on economic growth in Siak Riau Regency, and some economic growth variables had a positive and significant impact on the development index. people in Siak Riau Regency Period 2013 - 2017. The limitations of this study lie in the use of research variables using CSR as the influence of the human development index mediated by economic growth and the object of observation, thus providing opportunities for other researchers to conduct research with the same theme. the same and add another variable and a wider object. The implication of this research is that the implementation of CSR has a very important role in the human development index, where when the implementation of CSR is in accordance with the laws and regulations, it will have a positive impact in various fields such as economic growth and others.
\end{abstract}

Keywords: Corporate Social Responsibility, Human Development Index, Economic Growth, Sustainable Development

\title{
PENDAHULUAN
}

Tidak dapat dipungkiri bahwa CSR (Corporate Social Responsibility) telah dan akan terus berperan penting dalam wacana dan praktik bisnis di dunia. Isu global CSR ini juga sudah merambah ke semua sektor industri. Pemaknaan konsep dan pelaksanaan CSR terus mengalami perbaikan dan kemajuan yang nyata. Beberapa perusahaan di Indonesia telah melaksanakan CSR mereka untuk kegiatan yang bersifat pembangunan yang berkelanjutan (sustainability development) dan sebahagian dari mereka juga telah melaporkan pelaksanaan CSR tersebut baik secara terpisah dari Laporan Tahunan perusahaan berupa Laporan Keberlanjutan (Sustainability Reporting) maupun menjadi bagian dari Laporan Tahunannya. Pemerintah hendaknya dapat memberikan apresiasi lebih terhadap pelaksanaan CSR yang memenuhi kriteria tertentu yang dapat menimbulkan peningkatan pembangunan yang berkelanjutan (sustainability development improvement) bagi Indonesia. Pembentukan sinergi antara semua komponen yang terkait dengan CSR seperti perusahaan, masyarakat dan pemerintah, diharapkan akan dapat mengoptimalkan pelaksanaan kegiatan 
CSR tersebut dan memberikan multiplier efek yang lebih besar, dan dengan adanya sinergi ini, pelaksanaan kegiatan CSR akan dapat dijadikan salah satu mata rantai pembangunan Indonesia menuju Indonesia yang adil dan makmur. (Zahara dan Eliyanora, 2014).

Sustainability adalah tujuan akhir yang harus dicapai oleh semua perusahaan. Tujuan akhir tersebut diantaranya adalah menyeimbangkan antara kinerja ekonomi, kesejahteraan sosial, dan peremajaan serta pelestarian lingkungan hidup, dan proses mencapai tujuan akhir yang disebut sebagai sustainable development (pembangunan berkelanjutan). Sedangkan CSR adalah kendaraan untuk mencapai tujuan akhir tersebut, jadi CSR merupakan bagian dari kegiatan pembangunan yang berkelanjutan.

CSR yang kini marak diimplementasikan banyak organisasi, mengalami evolusi dan metamorfosis dalam rentang waktu yang cukup panjang. Pada saat industri berkembang setelah terjadi revolusi industri, kebanyakan organisasi masih memfokuskan dirinya sebagai organisasi yang mencari keuntungan belaka. Mereka memandang bahwa sumbangan kepada masyarakat cukup diberikan dalam bentuk penyediaan lapangan kerja, pemenuhan kebutuhan masyarakat melalui produknya, dan pembayaran pajak kepada negara. Seiring dengan berjalannya waktu, masyarakat tidak sekedar menuntut organisasi untuk menyediakan barang dan jasa yang diperlukan, melainkan juga menuntut untuk bertanggung jawab secara sosial. Kegiatan operasional organisasi umumnya juga memberikan dampak negatif, misalnya ekploitasi sumber daya dan rusaknya lingkungan di sekitar operasi organisasi atau ketimpangan ekonomi antara pelaku usaha dengan masyarakat disekitarnya. Kini persoalan-persoalan kemiskinan dan keterbelakangan yang semula terabaikan mulai mendapatkan perhatian lebih luas dari berbagai kalangan. Persoalan ini telah mendorong berkembangnya beragam aktivitas yang terkait dengan pengentasan kemiskinan dan keterbelakangan dengan mendorong berkembangnya sektor produktif dari masyarakat. 
Program CSR yang berkelanjutan diharapkan akan dapat membentuk atau menciptakan kehidupan masyarakat yang lebih sejahtera dan mandiri. Setiap kegiatan tersebut akan melibatkan semangat sinergi dari semua pihak secara terus menerus membangun dan menciptakan kesejahteraan dan pada akhirnya akan tercipta kemandirian dari masyarakat yang terlibat dalam program tersebut.

Namun muncul perbedaan pendapat kepada pemerintah untuk mengumpulkan dana CSR dalam satu skema pengumpulan nasional, kemudian, CSR dibagi-bagi ke daerah yang membutuhkan berdasarkan Indeks Pembangunan Manusia (Human Development Index/HDI). Jadi Indeks pembangunan manusia dapat dipakai sebagai indikator kebutuhan masingmasing daerah atas dana CSR. Semakin rendah angka HDI, semakin besar alokasi dana CSR yang diberikan. Namun, usulan pengumpulan secara nasional ini sedikit bertentangan dengan program CSR sebagai strategi bisnis perusahaan, program CSR yang diselenggarakan perusahaan di Indonesia bermanfaat bagi masyarakat. Praktek di berbagai negara, CSR merupakan program kesukarelaan yang saling menguntungkan antara perusahaan dan masyarakat. (Qosasi, 2010).

Pembangunan berkelanjutan adalah salah satu wacana sosial dan politik yang dominan di seluruh dunia saat ini, dan HDI telah menjadi isu penting perdebatan di banyak negara, Spangenberg meminjam konsep makro : Indeks Pembangunan Manusia (HDI) dan menurunkan CHDI (Corporate Human Development Index) dengan memproyeksikan kriteria dan kategori HDI UNDP (United Nations Development Programme) ke tingkat perusahaan, menggunakan selain pendekatan persediaan modal dan wacana tentang masa depan tenaga kerja. Komponen dasarnya adalah 1).umur panjang dan hubungan industri, 2).pendidikan, pengetahuan dan keterampilan, dan 3).standar hidup dan keadilan distribusi. (Spangenberg, J.H, 2016).

Banyak pendapat-pendapat tentang dampak dan peran CSR terhadap perekonomian masyarakat maupun daerah. Program CSR dapat mendukung 
pertumbuhan ekonomi serta daya saing daerah (Seperti Lampung). Perusahaan di Lampung dihimbau terus menggelorakan misinya yakni mendampingi, memfasilitasi, berbagi inspirasi, dan menjaga marwah semangat CSR. (Ridho, 2017).

CSR yang diberikan Perusahaan Harita Nickel, bisa dirasakan untuk meningkatkan kesejahteraan dan mendorong peningkatan ekonomi masyarakat, dan tentunya bisa dirasakan dampaknya bagi pertumbuhan ekonomi. (Lahabato, 2018).

Semua program CSR yang dilakukan perusahaan adalah untuk peningkatan pertumbuhan ekonomi masyarakat di sekitar perusahaan, serta untuk kesejahteraan baik di bidang pendidikan, kesehatan, lingkungan dan lainnya. (Lieman, 2018).

PT Adaro Indonesia menambah dana CSR pada tahun 2018 untuk mendukung pertumbuhan ekonomi di enam kabupaten termasuk Tabalong, Kalimantan Selatan. PT.Adaro sangat berkomitmen dengan program pemberdayaan dan meyakini penyaluran dana CSR merupakan salah satu stimulus penting untuk menumbuhkan ekonomi di daerah, yang pada akhirnya perusahaan menjadi bagian penting bagi masyarakat. (Dartaman, 2018).

Sementara itu ada sebanyak dua puluh dua perusahaan BUMN menyalurkan bantuan CSR senilai Rp.36 miliar kepada masyarakat Jawa Tengah, dan juga membangun sejumlah Balai Ekonomi Desa (Balkondes) dengan tujuan membantu perekonomian desa. Perusahaan milik negara dapat menjadi sarana untuk mengeksplorasi potensi di berbagai sektor ekonomi di Indonesia. Tujuannya adalah menggerakkan pertumbuhan ekonomi sekaligus menjadikan Indonesia sebagai negara kuat dan digdaya. (Soemarno, 2017).

Salah satu tujuan dari Program Kemitraan milik CSR-PKBL (Corporate Social Responsibility Program Kemitraan dan Bina Lingkungan) PT Phapros Tbk. adalah meningkatkan kualitas masyarakat dan kemampuan usaha kecil agar menjadi tangguh dan mandiri sehingga dapat mendorong pertumbuhan 
ekonomi serta tercipta pemerataan pembangunan dan perluasan lapangan kerja melalui berbagai macam bidang usaha. Sektor yang dibantu melalui dana CSR perusahaan adalah bidang pendidikan, kesehatan, infrastruktur, keagamaan, lingkungan, pariwisata, sosial budaya, pertanian, perikanan, peternakan dan pemberdayaan masyarakat. (Iswanto, 2015).

Kabupaten Siak, sampai tahun 2017 memiliki enam puluh enam perusahaan penyumbang dana CSR. Perusahaan tersebut merupakan perusahaan-perusahaan yang beroperasi di Kabupaten Siak yang terdiri dari berbagai sektor, antara lain sektor Migas enam perusahaan, kehutanan Pulp dan Paper sembilan perusahaan, perkebunan dua puluh sembilan perusahaan, Badan Usaha Milik Daerah (BUMD) tujuh, Badan Usaha Milik Negara (BUMN) delapan dan manufaktur tiga perusahaan. Jumlah dana CSR perusahaan dari tahun 2012 s/d 2017 yaitu tahun 2012 sebesar Rp.25,36 miliar, tahun 2013 sebesar Rp.34 miliar, tahun 2014 sebesar Rp.13,49 miliar, tahun 2015 sebesar Rp.17,09 milyar, tahun 2016 sebesar Rp.17,01 miliar dan tahun 2017 sebesar Rp.13,33 milliar. Total keseluruhan dana CSR perusahaan dari tahun 2012 sampai dengan 2017 sebesar Rp.120,85 miliar. (Syamsuar, 2018).

Dana tersebut tidak dihimpun oleh forum CSR, namun forum CSR hanya sebagai fasilitator terhadap program kegiatan prioritas yang diusulkan oleh pemerintah dan dilaksanakan oleh perusahaan. Sektor yang dibantu melalui dana CSR perusahaan adalah bidang pendidikan, kesehatan, infrastruktur, keagamaan, lingkungan, pariwisata, sosial budaya, pertanian, perikanan, peternakan dan pemberdayaan masyarakat. Dana dari program CSR merupakan salah satu potensi besar bagi pembangunan di daerah, oleh karena itu harus dikelola dengan baik, karena pembangunan daerah tidak hanya menjadi tanggung jawab pemerintah semata, akan tetapi peran dari pihak perusahaan juga diharapkan, dan diharapkan dunia usaha terus mencari peluang-peluang baru untuk berinvestasi sehingga akan menciptakan multi player effect yang besar dan berakibat terhadap pertumbuhan ekonomi. (Syamsuar, 2018). 
Propinsi Riau merupakan propinsi kedua di Sumatera yang memberikan kontribusi PDRB bagi negara, yaitu sebesar $4.75 \%$.

Gambar. 1.1.

Enam Propinsi dengan PDRB Terbesar

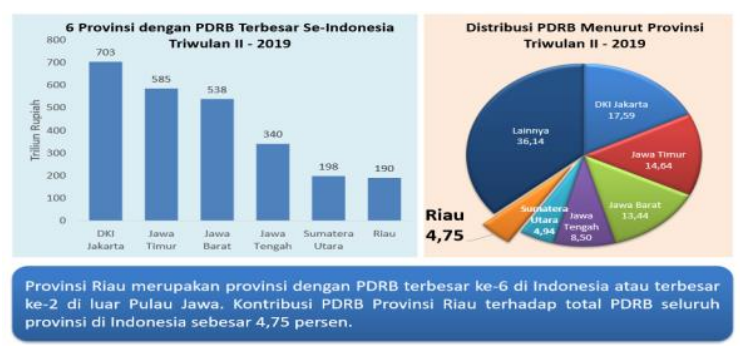

(Sumber : https://riau.bps.go.id/backend/materi_ind/materiBrsInd20190805120505.pdf)

Untuk itu, tertarik melihat daerah yang ada di Propinsi Riau, salah satunya Kabupaten Siak. Kabupaten Siak merupakan salah satu kabupaten dari sepuluh kabupaten yang ada di Propinsi Riau. Berdasarkan data Indeks Pembangunan Manusia tahun 2013 sampai tahun 2017, Indeks Pembangunan Manusia Kabupaten Siak termasuk tertinggi, artinya cukup baik. Namun jika melihat data Laju Pertumbuhan PDRB dari tahun 2015 - 2018, Kabupaten Siak termasuk rendah.

Tabel 1.1.

Indeks Pembangunan Manusia Kabupaten/Kota Riau Tahun 2013-2017

\begin{tabular}{lccccc}
\hline \hline $\begin{array}{c}\text { Kabupaten/Kota } \\
\text { District }\end{array}$ & 2013 & 2014 & 2015 & 2016 & 2017 \\
\hline \multicolumn{1}{c}{$(1)$} & $(2)$ & $(3)$ & $(4)$ & $(5)$ & $(6)$ \\
\hline $\begin{array}{l}\text { Kabupaten/Regency } \\
\text { 1. Kuantan Singingi }\end{array}$ & 66,65 & 67,47 & 68,32 & 68,66 & 69,53 \\
2. Indragiri Hulu & 66,68 & 67,11 & 68,00 & 68,67 & 68,97 \\
3. Indragiri Hilir & 63,44 & 63,80 & 64,80 & 65,35 & 66,17 \\
4. Pelalawan & 68,29 & 68,67 & 69,82 & 70,21 & 70,59 \\
5. Siak & 70,84 & 71,45 & 72,17 & 72,70 & 73,18 \\
6. Kampar & 70,46 & 70,72 & 71,28 & 71,39 & 72,19 \\
7. Rokan Hulu & 66,07 & 67,02 & 67,29 & 67,86 & 68,67 \\
8. Bengkalis & 70,60 & 70,84 & 71,29 & 71,98 & 72,27 \\
9. Rokan Hilir & 65,46 & 66,22 & 66,81 & 67,52 & 67,84 \\
10. Kepulauan Meranti & 62,53 & 62,91 & 63,25 & 63,90 & 64,70 \\
Kota/Municipality & & & & & \\
1. Pekanbaru & 78,16 & 78,42 & 79,32 & 79,69 & 79,97 \\
2. Dumai & 71,59 & 71,86 & 72,20 & 72,96 & 73,46 \\
\hline
\end{tabular}

(Sumber:https:/ / pekanbarukota.bps.go.id) 
Berdasarkan uraian latar belakang di atas, maka tujuan dari penelitian ini adalah untuk mengetahui 1). Pengaruh CSR terhadap Indeks Pembangunan Manusia, 2). Pengaruh CSR terhadap Pertumbuhan Ekonomi, 3). Pengaruh Pertumbuhan Ekonomi terhadap Indeks Pembangunan Manusia, 4). Pengaruh CSR dan Pertumbuhan Ekonomi terhadap Indeks Pembangunan Manusia, 5). Pengaruh CSR terhadap Indeks Pembangunan Manusia yang dimediasi oleh Pertumbuhan Ekonomi di Kabupaten Siak Riau Periode tahun 2013 - 2017. sebagai upaya Sustainable Development.

\section{Definisi Sustainable Development}

Istilah berkelanjutan itu mengacu kepada pemenuhan kebutuhan generasi sekarang tanpa merugikan kebutuhan generasi-generasi mendatang, atau proses pembangunan akan bisa dikatakan berkesinambungan apabila seluruh asset modal tetap atau meningkat dari waktu ke waktu. (Amalia, 2007).

Landasan sumber daya alam suatu negara serta mutu udara, air, dan tanah merupakan warisan untuk semua generasi. Oleh karena itu para perencana pembangunan menggunakan akuntansi lingkungan (environmental accounting) dalam kebijakannya. Pembuat kebijakan menetapkan tujuan tanpa kerugian neto atas asset lingkungan. Jika sumber daya lingkungan rusak atau habis di satu tempat, maka sumber daya dengan nilai yang sama atau yang lebih besar harus diciptakan di tempat lain.

Dalam akuntansi lingkungan, keseluruhan asset modal termasuk modal manufaktur (mesin, pabrik, jalan), modal manusia (pengetahuan, pengalaman, keterampilan), dan modal lingkungan (hutan, mutu tanah). Pembangunan berkelanjutan mengharuskan agar seluruh asset modal tersebut tidak berkurang, dan ukuran yang benar dari pendapatan nasional berkelanjutan atau produk nasional neto berkelanjutan adalah jumlah yang dapat dikonsumsikan tanpa mengurangi persediaan modal atau PNN = PNB - Dm Dn, dimana PNN adalah produk nasional neto berkelanjutan, Dm adalah penyusutan asset modal manufaktur dan Dn adalah penyusutan modal lingkungan (nilai moneter dari penyusutan lingkungan selama setahun). 
Ukuran yang lebih baik sebagai berikut: $\mathrm{PNN}=\mathrm{Dm}-\mathrm{Dn}-\mathrm{R}-\mathrm{A}$. Dimana $\mathrm{R}$ adalah pengeluaran untuk mengembalikan modal lingkungan (hutan, perikanan), dan A adalah pengeluaran untuk mencegah kerusakan modal lingkungan (pencemaran udara, air, tanah). (Kertonegoro, 2001).

CSR sebagai tanggung jawab sosial dan lingkungan di Indonesia telah di atur melalui Undang-Undang Nomor 40 Tahun 2007 tentang Perseroan Terbatas yang menggantikan Undang-Undang Nomor 1 Tahun 1995 tentang Perseroan Terbatas yang selanjutnya disingkat UUPT bahwa CSR sebagaimana yang termuat dalam Pasal 1 Ayat 3 berbunyi “Tanggung jawab sosial dan lingkungan adalah komitmen Perseroan untuk berperan serta dalam pembangunan ekonomi berkelanjutan guna meningkatkan kualitas kehidupan dan lingkungan yang bermanfaat, baik bagi Perseroan sendiri, komunitas setempat, maupun masyarakat pada umumnya" (Nurlaela, 2019).

Kondisi lokasi tempat berdirinya suatu perusahaan dapat menjadi tolok ukur mampu tidaknya perusahaan untuk berkompetisi. Oleh sebab itu, CSR harus dipahami secara utuh dalam 1 model piramida. CSR adalah bentuk dari rasa peduli suatu perusahaan yang berdasar pada triple bottom lines, yaitu profit, people dan planet (3P) (Prasetyo \& Meiranto, 2017). Hubungan Sustainable Development dengan CSR, dimana Sustainable development menjadi tujuan dari CSR karena bukan hanya pembangunan komunitas atau Community Development yang menjadi inti tujuan dari CSR melainkan bagaimana Community Development tersebut bisa terus eksis berada dalam masyarakat sebagai upaya untuk keseimbangan lingkungan dan alam. (Rafsanjani, Nurdiana, 2008).

2. Definisi Corporate Social Responsibility (CSR)

Secara sederhananya, CSR adalah sebuah konsep dan tindakan yang dilakukan oleh sebuah perusahaan sebagai rasa tanggung jawabnya terhadap sosial dan lingkungan sekitar dimana perusahaan tersebut berdiri. Tanggung jawab sosial perusahaan atau Corporate Social Responsibility (CSR) perusahaan kini mulai ramai diperbicangkan, namun belum terdapat kesamaan definisi 
dari berbagai kalangan. Menurut The World Business Council on Sustainable Development (WBCSD) menyatakan CSR adalah suatu komitmen dari perusahaan untuk melaksanakan etika keperilakuan (behavioural ethics) dan berkontribusi terhadap pembangunan ekonomi yang berkelanjutan (sustainable economic development) (Sari, 2012). Tujuan CSR adalah untuk merangkul tanggung jawab atas tindakan perusahaan dan mendorong dampak positif melalui kegiatannya terhadap lingkungan, konsumen, karyawan, komunitas, pemangku kepentingan, dan semua anggota ruang publik lainnya (Fontaine, 2013).

Evaluasi merupakan hal penting yang harus dilakukan untuk keberlanjutan perusahaan, hubungan baik perusahaan dan masyarakat, serta peran perusahaan dalam pembangunan nasional. Dalam rangka evaluasi, diperlukan pemahaman dan pemetaan masyarakat, di mana perusahaan perlu mengenali secara baik dan cermat tentang kondisi masyarakat di sekitarnya. Dengan demikian, diharapkan perusahaan dapat memutuskan program CSR yang tepat untuk pemberdayaan (Retnaningsih, 2015).

Pada dasarnya CSR adalah bentuk tanggung jawab sebuah perusahaan terhadap stakeholder atau pemangku kepentingan. Menurut para ahli, CSR memiliki tiga definisi, yakni : 1). Melakukan tindakan sosial, termasuk di dalamnya adalah kepedulian terhadap lingkungan hidup yang diharuskan dalam peraturan perundangan-undangan 2). Komitmen usaha yang dilakukan secara etis, beroperasi secara resmi, serta dapat berkontribusi terhadap peningkatan ekonomi yang di iringi dengan peningkatan kualitas hidup karyawan termasuk keluarganya, komunitas lokal, serta masyarakat luas. 3). Komitmen bisnis untuk turut berkontribusi dalam pembangunan ekonomi yang berkelanjutan, bekerja dengan karyawan perusahaan, keluarga karyawan, komunitas lokal, serta masyarakat luas dalam rangka untuk meningkatkan kualitas hidup bersama. (https://sahabatnesia.com)./pengertian-manfaatfungsi-contoh-csr-adalah/) 
Corporate Social Responsibility juga merupakan laporan mengenai kinerja organisasi dalam pembangunan keberlanjutan yang terdiri dari kebijakan ekonomi, lingkungan, dan sosial. Tujuan utama pengungkapan Corporate Social Responsibility bagi perusahaan yaitu sebagai bentuk tanggungjawab atas aktivitas bisnisnya (Avram \& Avasilcai, 2014). CSR biasanya dilaporkan dalam sebuah laporan tahunan perusahaan yang dianggap sebagai sarana komunikasi terbaik bagi perusahaan dengan pihak eksternal. Seperti tersuratdalam PSAK No.1 Tahun 2009 Paragraf 9 tentang Penyajian Laporan Keuangan, bagian Tanggung Jawab atas Laporan Keuangan (Budiasih, 2020).

Pertanggungjawaban sosial perusahaan diungkapkan di dalam laporan yang disebut dengan Sustainability Reporting. Sustainability Reporting adalah pelaporan mengenai kebijakan ekonomi, lingkungan dan sosial, pengaruh dan kinerja organisasi dan produknya di dalam konteks pembangunan berkelanjutan (Handriani, 2011). Pengungkapan CSR yang dilakukan oleh manajemen memiliki dampak yang positif dan negatif. Dampak negatif dari pengungkapan CSR adalah manajemen dapat menggunakan pengungkapan CSR untuk menutupi perilaku manajemen laba yang dapat menurunkan kualitas laba. Di lain pihak, dengan pengungkapan CSR maka manajemen dapat menjalin hubungan jangka panjang dengan stakeholders untuk memberikan image yang positif terkait dengan kondisi perusahaan (Ibrahim, 2014).

CSR akan memberikan hasil baik langsung maupun tidak langsung pada keuangan perusahaan di masa mendatang. Investor juga ingin investasinya dan kepercayaan masyarakat terhadap perusahaannya memiliki citra yang baik di mata masyarakat umum. Dengan demikian, apabila perusahaan melakukan program- program CSR diharapkan keberlanjutan, sehingga perusahaan akan berjalan dengan baik. Oleh karena itu, program CSR lebih tepat apabila digolongkan sebagai investasi dan harus menjadi strategi bisnis dari suatu perusahaan (Siregar, 2007). Perusahaan yang ikut terlibat dalam aktivitas sosial 
akan mendapatkan nilai tambah baik dari segi ekonomi maupun keuangan (Carroll et al., 2010). Hal ini sejalan dengan pernyataan (Yuliyanti, 2019) CSR merupakan bentuk tanggung jawab perusahaan dalam memperbaiki kesenjangan sosial dan kerusakan lingkungan yang terjadi akibat aktivitas operasional perusahaan. Semakin banyak bentuk pertanggungjawaban yang dilakukan perusahaan terhadap lingkungannya, image perusahaan menjadi meningkat

\section{Definisi Pertumbuhan Ekonomi}

Pertumbuhan ekonomi adalah proses perubahan kondisi berkesinambungan menuju keadaan yang lebih baik selama periode tertentu. Pertumbuhan ekonomi merupakan salah satu indikator keberhasilan pembangunan di suatu perekonomian. Kesejahteraan dan kemajuan suatu perekonomian ditentukan oleh besarnya pertumbuhan yang ditunjukkan oleh perubahan output nasional. Adanya perubahan output dalam perekonomian merupakan analisis ekonomi jangka pendek (Wihastuti, 2008). Pertumbuhan ekonomi berkaitan dengan kenaikan produksi suatu negara atau kenaikan pendapatan per kapita suatu negara. Oleh karena itu pertumbuhan ekonomi erat kaitannya dengan produk domestik bruto (PDB) atau produk domestik regional bruto (PDRB) jika dalam lingkup daerah. Beberapa hasil kajian dan penelitian telah diperoleh bahwa pertumbuhan ekonomi, IPM, dan kemiskinan memiliki keterkaitan yang erat (Suliswanto, 2010).

Para ekonom memandang bahwa pertumbuhan pendapatan nasional riil (GNP) dapat digunakan sebagai sebuah ukuran kinerja perekonomian suatu negara. Oleh karena itu pemahaman terhadap sifat dan sebab-sebab terjadinya pertumbuhan ekonomi, sangatlah penting sekali untuk diperdalam. Ada empat faktor utama yang mempengaruhi pertumbuhan ekonomi suatu masyarakat (negara), yaitu 1). akumulasi modal, termasuk semua investasi baru yang berwujud tanah (lahan), peralatan fisik (mesin-mesin), dan sumber daya manusia, 2). Pertumbuhan penduduk, 3). Kemajuan teknologi, 4). Sumber daya institusi (sistem kelembagaan). (Arsyad, 2010). 


\section{Definisi Indeks Pembangunan Manusia}

Indeks Pembangunan Manusia (IPM) menjelaskan bagaimana penduduk dapat mengakses hasil pembangunan dalam memperoleh pendapatan, kesehatan, pendidikan, dan sebagainya. IPM diperkenalkan oleh United Nations Development Programme (UNDP) pada tahun 1990 dan dipublikasikan secara berkala dalam laporan tahunan Human Development Report (HDR). IPM dibentuk oleh 3 (tiga) dimensi dasar : Umur panjang dan hidup sehat (kesehatan), Pengetahuan (pendidikan), Standar hidup layak (pendapatan). (Arsyad, 2010). Dari tiga dimensi tersebut diturunkan menjadi empat indikator yaitu angka harapan hidup saat lahir $(\mathrm{AHH})$ untuk mengukur dimensi umur panjang dan hidup sehat, rata-rata lama sekolah dan harapan lama sekolah untuk mengukur dimensi pengetahuan, dan produk nasional bruto (PNB) perkapita untuk mengukur dimensi standar hidup layak (Arafat et al., 2020).

IPM berperan penting dalam pembangunan perekonomian modern sebab pembangunan manusia yang baik akan menjadikan faktor-faktor produksi mampu di maksimalkan. Mutu penduduk yang baik akan mampu untuk berinovasi mengembangkan faktor- faktor produksi yang ada. Selain dari pada itu pembangunan manusia yang tinggi mengakibatkan jumlah penduduk akan tinggi pula sehingga akan menaikkan tingkat konsumsi (Susanto \& Lucky, 2002). Manfaat IPM merupakan indikator penting untuk mengukur

keberhasilan dalam upaya membangun kualitas hidup manusia (masyarakat/penduduk), IPM dapat menentukan peringkat atau level pembangunan suatu wilayah/negara, Bagi Indonesia, IPM merupakan data strategis karena selain sebagai ukuran kinerja Pemerintah, IPM juga digunakan sebagai salah satu alokasi penentuan Dana Alokasi Umum (Hakim, 2002).

\section{METODOLOGI PENELITIAN}

Dalam penelitian ini, penulis menggunakan penelitian kuantitatif dimana proses penggalian informasi diwujudkan dalam bentuk angka-angka sebagai alat untuk menemukan keterangan mengenai apa yang diketahui. 
Penelitian kuantitatif lebih menekankan fenomena-fenomena objektif, dan maksimalisasi objektivitas, desain penelitian ini dilakukan dengan menggunakan angka-angka, pengolahan statistik, struktur dan percobaan terkontrol (Moleong, 2011:2). Penelitian kuantitatif mencakup setiap jenis penelitian yang didasarkan atas perhitungan persentase, rata-rata, dan perhitungan lainnya. Dengan kata lain penelitian ini menggunakan perhitungan angka atau kuantitas (Moleong, 2011:1).

Berdasarkan waktunya penelitian ini adalah cross sectional yaitu penelitian yang dilakukan pada periode waktu tertentu dan untuk mengumpulkan data yang berkaitan dalam rangka menemukan jawaban atas pertanyaan penelitian (Sekaran \& Bougie, 2010:178).

\section{HASIL DAN KESIMPULAN}

1. Regresi Berganda

Untuk melihat koefisien determinasi dan koefisien jalur masing-masing variabel yang diteliti dengan menggunakan alat analisis software pengolah data SPSS 26.

Tabel. 1.

Koefisien Determinasi

Struktur Model 1

\begin{tabular}{|c|c|c|c|c|c|}
\hline \multicolumn{6}{|c|}{ Model Summary } \\
\hline Model & $\mathrm{R}$ & R Square & $\begin{array}{c}\text { Adjusted R } \\
\text { Square }\end{array}$ & $\begin{array}{l}\text { Std. Error of } \\
\text { the Estimate }\end{array}$ & $\begin{array}{l}\text { Durbin- } \\
\text { Watson }\end{array}$ \\
\hline 1 & $.809^{\mathrm{a}}$ & .655 & .540 & .86025 & 1.321 \\
\hline \multicolumn{6}{|c|}{ a. Predictors: (Constant), CSR } \\
\hline \multicolumn{6}{|c|}{ b. Dependent Variable: $G$} \\
\hline
\end{tabular}

(Sumber : Olahan Data SPSS) 
Tabel. 2.

Koefisien Jalur Struktur Model 2

\begin{tabular}{|c|c|c|c|c|c|c|c|c|}
\hline \multicolumn{9}{|c|}{ Coefficients $^{a}$} \\
\hline \multirow[b]{2}{*}{ Model } & & \multicolumn{2}{|c|}{ Unstandardized Coefficients } & \multirow{2}{*}{$\begin{array}{c}\text { Standardized } \\
\text { Coefficients } \\
\text { Beta }\end{array}$} & \multirow[b]{2}{*}{$t$} & \multirow[b]{2}{*}{ Sig. } & \multicolumn{2}{|c|}{ Collinearity Statistics } \\
\hline & & $B$ & Std. Error & & & & Tolerance & VIF \\
\hline \multirow[t]{3}{*}{1} & (Constant) & 71.902 & .087 & & 827.870 & .000 & & \\
\hline & CSR & $2.965 \mathrm{E}-11$ & .000 & .271 & 5.888 & .028 & .345 & 2.898 \\
\hline & G & .894 & .034 & 1.206 & 26.208 & .001 & .345 & 2.898 \\
\hline
\end{tabular}

(Sumber : Olahan Data SPSS)

Struktur Model 2 : $\quad \mathrm{Y}=1,206 \mathrm{Z}+0,271 \mathrm{X}+\mathrm{e} 2$

Hasil uji-t memberikan nilai sig. CSR sebesar 0,028 lebih kecil daripada $\mathrm{a}=0,05$ Berarti Hipotesis H1 diterima, maka secara parsial CSR berpengaruh terhadap Indeks Pembangunan Manusia, sehingga koefisien jalur $\gamma_{21}=0,271$ signifikan.

Dari hasil uji-t memberikan nilai sig. Pertumbuhan Ekonomi sebesar 0,001 lebih kecil dari $a=0,05$, Berarti Hipotesis H3 diterima, maka secara parsial Pertumbuhan Ekonomi berpengaruh terhadap Indeks Pembangunan Manusia, sehingga koefisien jalur $\beta_{21}=1,206$ signifikan.

Tabel. 3.

Uji-F Struktur Model 2

\begin{tabular}{|c|c|c|c|c|c|c|}
\hline \multicolumn{7}{|c|}{ ANOVA $^{a}$} \\
\hline \multicolumn{2}{|c|}{ Model } & $\begin{array}{l}\text { Sum of } \\
\text { Squares }\end{array}$ & df & Mean Square & $\mathrm{F}$ & Sig. \\
\hline \multirow[t]{3}{*}{1} & Regression & 3.531 & 2 & 1.766 & 683.618 & $.001^{b}$ \\
\hline & Residual & .005 & 2 & .003 & & \\
\hline & Total & 3.536 & 4 & & & \\
\hline \multicolumn{7}{|c|}{ a. Dependent Variable: HDI } \\
\hline \multicolumn{7}{|c|}{ b. Predictors: (Constant), G, CSR } \\
\hline
\end{tabular}


(Sumber : Olahan Data SPSS)

Secara simultan hasil uji-F memberikan nilai sig.F sebesar 0,001 lebih kecil dari $a=0,05$. Berarti Hipotesis H4 diterima, maka secara simultan CSR dan Pertumbuhan Ekonomi berpengaruh terhadap Indeks Pembangunan Manusia.

2. Pengaruh CSR terhadap Indeks Pembangunan Manusia

Dari uji-t statistik dengan SPSS memberikan hasil nilai Sig. CSR terhadap Indeks Pembangunan Manusia yang lebih kecil dari $<a=0,05$. Hal ini menunjukkan bahwa terdapat pengaruh yang positif dan signifikan CSR terhadap Indeks Pembangunan Manusia di Kabupaten Siak Riau periode tahun 2013-2017. Hal ini memberikan petunjuk bahwa jika CSR naik maka akan meningkatkan Indeks Pembangunan Manusia. Berati Hipotesis H1 diterima.

Hasil penelitian ini didukung oleh penelitian Wahyuningrum dkk, (2014), yang menunjukkan hasil bahwa ada pengaruh variabel CSR terhadap variabel Pemberdayaan Masyarakat. Demikian pula penelitian Cahya dkk, (2014), memberikan hasil bahwa ada pengaruh variabel CSR terhadap Kesejahteraan Keluarga di Sekitar Tambang.

3. Pengaruh CSR terhadap Pertumbuhan Ekonomi

Dari uji-t statistik memberikan hasil nilai Sig. CSR terhadap Pertumbuhan Ekonomi yang lebih besar dari $>_{a}=0,05$. Hal ini menunjukkan bahwa tidak ada pengaruh CSR terhadap Pertumbuhan Ekonomi di Kabupaten Siak Riau periode tahun 2013-2017. Diharapkan seiring dengan perkembangan waktu, program CSR terus berjalan dan perekonomian masyarakat dapat lebih berkembang sehingga dapat mendorong perekonomian daerah.

\section{Pengaruh Pertumbuhan Ekonomi terhadap Indeks Pembangunan Manusia}

Dari uji-t statistik dengan SPSS memberikan hasil nilai Sig. Pertumbuhan Ekonomi terhadap Indeks Pembangunan Manusia yang lebih kecil dari < $a=0,05$. Hal ini menunjukkan bahwa terdapat pengaruh yang positif dan signifikan Pertumbuhan Ekonomi terhadap Indeks Pembangunan Manusia di Kabupaten Siak Riau Periode 2013 - 2017. Hal ini memberikan petunjuk bahwa 
jika Pertumbuhan Ekonomi naik maka secara langsung akan meningkatkan Indeks Pembangunan Manusia.

Hasil penelitian ini didukung oleh penelitian Muda dkk, (2014), (N. Dewi, 2016) dan penelitian yang dilakukan oleh (Yusuf, 2014) yang menunjukkan hasil bahwa ada pengaruh variabel Pertumbuhan Ekonomi terhadap variabel Indeks Pembangunan Manusia. Demikian pula penelitian Adelfina dan Made, (2016), (N. L. S. Dewi \& Sutrisna, 2014), dan (Hakim, 2013) memberikan hasil bahwa Pertumbuhan Ekonomi berpengaruh terhadap Indeks Pembangunan Manusia. Selanjutnya penelitian dari (Maratade et al., 2016) menyatakan bahwa Pertumbuhan Ekonomi mempunyai hubungan kausalitas dengan Indeks Pembangunan Manusia dan sebaliknya, Indeks Pembangunan Manusia mempunyai hubungan kausalitas dengan Pertumbuhan Ekonomi.

5. Pengaruh CSR dan Pertumbuhan Ekonomi terhadap Indeks Pembangunan Manusia

Dari uji-F statistik dengan SPSS memberikan hasil nilai Sig. F CSR dan Pertumbuhan Ekonomi terhadap Indeks Pembangunan Manusia yang lebih kecil dari $<a=0,05$. Hal ini menunjukkan bahwa terdapat pengaruh bersamasama yang positif dan signifikan CSR dan Pertumbuhan Ekonomi terhadap Indeks Pembangunan Manusia di Kabupaten Siak Riau periode 2013 -2107. Hal ini memberikan petunjuk bahwa jika CSR dan Pertumbuhan Ekonomi naik maka akan meningkatkan Indeks Pembangunan Manusia.

Hasil penelitian ini didukung oleh penelitian Wahyuningrum dkk, (2014), yang menunjukkan hasil bahwa ada pengaruh variabel CSR terhadap variabel Pemberdayaan Masyarakat. Demikian pula penelitian Cahya dkk, (2014), memberikan hasil bahwa ada pengaruh variabel CSR terhadap Kesejahteraan Keluarga di Sekitar Tambang.

6. Pengaruh CSR terhadap Indeks Pembangunan Manusia yang dimediasi oleh Pertumbuhan Ekonomi

Dari uji statistik dengan SPSS memberikan hasil nilai Sig. CSR terhadap Indeks Pembangunan Manusia yang lebih kecil dari $<a=0,05$. Hal ini menunjukkan bahwa terdapat pengaruh yang positif dan signifikan CSR 
terhadap Indeks Pembangunan Manusia di Kabupaten Siak Riau. Hal ini memberikan petunjuk bahwa jika CSR naik berdampak meningkatkan Indeks Pembangunan Manusia. Penelitian yang dilakukan oleh Bagus \& Nyoman, mendekati sama dengan penelitian ini, dengan judul Pengaruh Belanja Modal Terhadap Indeks Pembangunan Manusia Melalui Pertumbuhan Ekonomi sebagai Variabel Intervening Propinsi Bali Periode 2008-2013 (Bagus \& Nyoman, 2015).

\section{KESIMPULAN}

Penelitian tentang pengaruh CSR terhadap pertumbuhan ekonomi masih sangat kurang, hasil penelitian ini menunjukkan bahwa tidak ada pengaruh CSR terhadap pertumbuhan ekonomi, dan hasilnya negatif. Namun ada penelitian terdahulu yang menunjukkan berpengaruh positif. Untuk penelitian selanjutnya mungkin dapat dikembangkan lagi dengan menambah jumlah variabel independen yang lebih berarti atau menambah jumlah sampel. Secara parsial CSR berpengaruh positif dan signifikan terhadap Indeks Pembangunan Manusia di Kabupaten Siak Riau periode 2013-2017, Secara parsial CSR tidak berpengaruh dan negatif signifikan terhadap Pertumbuhan Ekonomi di Kabupaten Siak Riau periode 2013-2017, Secara parsial Pertumbuhan Ekonomi berpengaruh positif dan signifikan terhadap Indeks Pembangunan Manusia di Kabupaten Siak Riau periode 2013-2017. Secara simultan CSR dan Pertumbuhan Ekonomi, berpengaruh positif dan signifikan terhadap Indeks Pembangunan Manusia di Kabupaten Siak Riau periode 2013-2017. CSR berpengaruh secara langsung terhadap indeks pembangunan manusia di Kabupaten Siak Riau periode 2013-2017. CSR berdampak kepada peningkatan investasi ataupun modal bagi perekonomian rakyat, dan berimplikasi kepada keseimbangan perusahaan, masyarakat (konsumen) dan pemerintah serta lingkungan, untuk tercapainya sustainable development. 


\section{IMPLIKASI PENELITIAN}

Implikasi penelitian ini yaitu penerapan CSR mempunyai peranan yang sangat penting dalam indeks pembangunan manusia, dimana ketika penerapan CSR sesuai dengan aturan perundang-undangan, akan membawa dampak yang positif diberbagai bidang seperti pertumbuhan ekonomi dan lainnya.

\section{REFERENSI}

Adelfina dan I Made Jember, (2016), Pengaruh Pertumbuhan Ekonomi, Kemiskinan, dan Belanja Daerah Terhadap Indeks Pembangunan Manusia di Kabupaten Kota Provinsi Bali Periode 2005-2013, E-Jurnal EP Unud Vol.5. No.10 , 5 [10] : 1011-1025 ISSN: 2303-0178, Fakultas Ekonomi dan Bisnis Universitas Udayana, Bali.

Algifari, (2017), Analisis Regresi untuk Bisnis dan Ekonomi, BPFE Yogyakarta. Amalia, Lia, (2007), Ekonomi Pembangunan, Jakarta, Graha Ilmu.

Arafat, L., Wiwiek Rindayati, \& Sahara. (2020). Faktor-Faktor yang Memengaruhi Indeks Pembangunan Manusia di Provinsi Kalimantan Tengah. Jurnal Ekonomi Dan Kebijakan Pembangunan, 7(2), 140-158. https:// doi.org/10.29244/jekp.7.2.2018.140-158

Arsyad, Lincolin, (2010), Ekonomi Pembangunan, STIM YKPN Yogyakarta.

Avram, E., \& Avasilcai, S. (2014). Business Performance Measurement in Relation to Corporate Social Responsibility: A conceptual Model Development. Procedia - Social and Behavioral Sciences, 109, 1142-1146. https:/ / doi.org/10.1016/J.SBSPRO.2013.12.601

Bagus \& Nyoman, (2015), Pengaruh Belanja Modal Terhadap Indeks Pembangunan Manusia Melalui Pertumbuhan Ekonomi sebagai Variabel Intervening Propinsi Bali, E-Jurnal Ekonomi Pembangunan Udayana Vol.4, No.10, Oktober 2015, Fakultas Ekonomi dan Bisnis Universitas Udayana Bali. 
BPS RIAU, https://riau.bps.go.id/backend/materi_ind/materiBrsInd20190805120505.pdf

Budiasih, I. D. N. A. A. dan I. G. A. N. (2020). Faktor-Faktor yang Mempengaruhi Pengungkapan Corporate Social Responsibility. E-JURNAL AKUNTANSI, 30, 2525-2539.

Carroll, A. B., Shabana, K. M., \& Scherer, R. W. (2010). The Business Case for Corporate Social Responsibility: A Review of Concepts, Research and Practicei jmr_275 85..106. International Journal Of Management Reviews, 12(1), 85-105. https:// doi.org/10.1111/j.1468-2370.2009.00275.x

Cahya, Gilar Nirmaya, Istiqlaliyah Muflikhati, Megawati Simanjuntak, (2014), Corporate Social Responsibility (CSR)Terhadap Kesejahteraan Keluarga di Sekitar Tambang, , Jur. Ilm. Kel. \& Kons., Januari 2014, p : 19-29 Vol. 7, No. 1 ISSN : 1907 - 6037, Departemen Ilmu Keluarga dan Konsumen, Fakultas Ekologi Manusia, Institut Pertanian Bogor.

Dartaman, Rizki, (12/04/2018), Adaro Tambah Dana CSR untuk Dorong Pertumbuhan, Diakses Tgl. 10/01/2020, https: //www. republika.co.id /berita/ekonomi/ korporasi/18/04/12/p71vag377-adaro-tambah-danacsr-untuk-dorong-pertumbuhan

Denny Maulasa, (08/05/2011), Antam Upayakan Pertumbuhan Ekonomi Masyarakat Sekitar Tambang, Diakses Tgl. 10/01/2020, https://investor.id/archive/antam-upayakan-pertumbuhan-ekonomimasyarakat-sekitar-tambang.

Dewi, N. (2016). Pengaruh Kemiskinan Dan Pertumbuhan Ekonomi Terhadap Indeks Pembangunan Manusia Di Provinsi Riau. Jurnal Online Mahasiswa Fakultas Ekonomi Universitas Riau, 4(1), 870-882.

Dewi, N. L. S., \& Sutrisna, I. K. (2014). Pengaruh Komponen Indeks Pembangunan Manusia Terhadap Pertumbuhan Ekonomi Provinsi Bali. EJurnal EP Unud, 3(3), 106-114. 
Fontaine, M. (2013). Corporate Social Responsibility and Sustainability: The New Bottom Line? International Journal of Business and Social Science, 4(4), 110-119. www.ijbssnet.com

Hakim, M. B. S. dan A. (2013). Indeks Pembangunan Manusia. Economia, 9(1), $18-26$.

Hakim, Abdul, (2002), Ekonomi Pembangunan, FE UII Yogyakarta, Ekonisia.

Harinowo, Cyrillus, (24/12/2018), Dorong Pertumbuhan Ekonomi Indonesia, BCA Bina 12 Desa Wisata, Diakses Tgl. 10/01/2018. https:// www.wartaekonomi.co.id/ read196404/ dorong- pertumbuhanekonomi- indonesia- bca- bina- 12- desa-wisata.html.

Heryanto, Imam dan Totok Triwibowo, (2018), Path Analysis Menggunakan SPSS dan Excel, Bandung, Informatika.

Handriani, E. (2011). Pengaruh Pengungkapan Corporate Social Responsibility Terhadap Earning Response Coefficient. Jurnal Dinamika Manajemen, 2(1), 17-25. http://journal.unnes.ac.id/nju/index.php/jdm

Ibrahim, H. 2011. F. - faktor yang berhubungan dengan kejadian I. pada anak B. di wilayah P. B. K. B. T. 2011. T. P. P. U. (2014). Pengaruh Corporate Social Responsibility (CSR) Terhadap Kualitas Laba Dengan Corporate Governance Sebagai Variabel Moderating. Akuntansi Dan Auditing, 11(1), $38-60$.

Iswanto, (25/03/201), Mendorong Pertumbuhan Ekonomi Melalui UMKM, Diakses Tgl. 10/01/2020, https:// www.phapros. co.id/ id/csr/ csr-news/ boosting_the_ economic _ growth_ through_micro_small_and_medium_business-1212.

Kertonegoro, Sentanoe, (2001), Ekonomi Pembangunan, FE-Atmajaya Jakarta Yayasan Tenaga Kerja Indonesia. 
Lahabato, Abdurahman, (16/12/2018), Dana CSR Harita Nickel Akan Dorong Ekonomi Masyarakat, Diakses Tgl.10/01/2020, https:// www.beritasatu.com/ nasional/ 528094/dana-csr-harita-nickel-akandorong-ekonomi-masyarakat.

Lieman, Alexander, (16/12/2018), Dana CSR Harita Nickel Akan Dorong Ekonomi Masyarakat, Diakses Tgl.10/01/2020, https:// www.beritasatu.com/ nasional/ 528094/dana-csr-harita-nickel-akandorong-ekonomi-masyarakat.

Maratade, S. Y., Rotinsulu, D. C., \& Niode, A. O. (2016). Analisis Pertumbuhan Ekonomi dan Indeks Pembangunan Manusia di Provinsi Sulawesi Utara. Berkala Ilmiah Efisien, 16(01), 328-338.

Marinko `Skare \& Tea Golja, (2014), The impact of government CSR supporting policies on economic growth, Juraj Dobrila University of Pula, Faculty of Economics and Tourism “Dr.MijoMirkovi'c”, Preradovi'ceva1/1,52100 Pula, Croatia Received 30 November 2013; received in revised form 16 December 2013; accepted 12 January 2014.

Muda, Iskandar, Syafrizal Helmi, Azizul Kholis, (2014), Kajian Pengaruh Indeks Kemahalan Konstruksi (IKK), Pertumbuhan Ekonomi dan Alokasi Belanja Modal Terhadap Indeks Pembangunan Manusia (IPM) Di Sumatera Utara. Jurnal Dinamika Akuntansi dan Bisnis Vol. 1, No. 1, Maret 2014 Hal. 1229, Fakultas Ekonomi USU dan Fakultas Ekonomi Unimed.

Muhammad Elwan ${ }^{1}$, La Ode, Irfan Ido ${ }^{2}$, La Ode Alwi ${ }^{2}$,Hendrik Wanda Putra ${ }^{3}$, (2018), Kebijakan Corporate Social Responsibility (CSR) Pertambangan dan Pengaruhnya Terhadap Kesejahteraan Masyarakat (Studi Kasus pada Desa Koeono Kecamatan Palangga Selatan Kabupaten Konawe Selatan), Jounal publiuho, Faculty of Socialand Political Science Halu Oleo University, Kendari, Southeast Sulawesi, Indonesia. ISSN:2460-058X, e-ISSN:26211351. Open Accessat : http : //ojs.uho.ac.id/ index.php/ PUBLICUHO). 
Nurlaela, Lela (2019), Model Corporate Social Responsibility (CSR), Ponorogo, Myria Publisher.

Prasetyo, A., \& Meiranto, W. (2017). Pengaruh Corporate Social Responsibility Terhadap Kinerja Keuangan Perusahaan Manufaktur Yang Terdaftar Di BEI. Diponegoro Juournal Of Accounting, 6(3), 1-12.

Punita Kumar-Sinha, (06/08/2015), Corporate Social Responsibility Boosting India's Economy, Diakses Tgl.10/01/2020, https://borgenproject.org/corporatesocial-responsibility-in-india/).

Qosasi, (10/12/2010), Pemerintah Pusatkan Dana CSR, Diakses 10/01/2020, https://www.hukumonline.com/berita/baca/lt4d02034b92bbe/pemerintah-pusatkan-dana-csr/).

Rafsanjani, Nurdiana, (2008), Sustainable development (Pembangunan Berkelanjutan), Diakses Tgl.10/01/2020, $\underline{\text { https:// }}$ rexxarsosio. wordpress. com/ 2008/05/13/ sustainable- developmentpembangunan-berkelanjutan/)

Retnaningsih, H. (2015). Permasalahan Corporate Social Responsibility (CSR) Dalam Rangka Pemberdayaan Masyarakat. Aspirasi, 6(2), 177-188.

Ridho, Muhammad, (08/07/2017), Pertumbuhan Ekonomi Meningkat, Ridho: Karena Dukungan CSR dan Perusahaan, Diakses 10/01/2020, http:/ / rilis.id/pertumbuhan-ekonomi-meningkat-ridho-karenadukungan-csr-dan-perusahaan.html.

Sahabatnesia.com, Diakses Tgl. (10/01/2020), https://sahabatnesia.com./pengertian-manfaat-fungsi-contoh-csradalah/

Sari, R. A. (2012). Pengaruh Karakteristik Perusahaan Terhadap Corporate Social Responsibility Disclosure Pada Perusahaan Manufaktur Yang Terdaftar Di Bursa Efek Indonesia. Nominal, Barometer Riset Akuntansi Dan Manajemen, 1(2). https:/ / doi.org/10.21831/nominal.v1i2.1002 
Siregar, C. (2007). Analisis Sosiologis Terhadap Implementasi Corporate Social Responsibility Pada Masyarakat Indonesia. Jurnal Sosioteknologi, 6(12), 285288-288. https://media.neliti.com/media/publications/41654-ID-analisissosiologis-terhadap-implementasi-corporate-social-responsibility-padam.pdf

Soemarno,Rini, (22/4/2017), BUMN Salurkan Dana CSR Rp36 Miliar di Jawa Tengah, Diakses Tgl.10/01/2020, https:// ekonomi.bisnis.com/ read/20170422 /309/647388/bumn-salurkan-dana-csr-rp36-miliar-dijawa-tengah.

Spangenberg, J.H. (2016), The Corporate Human Development Index CHDI : a tool for corporate social sustainability management and reporting Journal of Cleaner Production. 134 (Part A), 414 - 424.

Supardi, (2016), Aplikasi Statistika Dalam Penelitian, Konsep Statistika yang lebih Komprehensif, Jakarta, Smart Change Publication..

Suliswanto, M. S. W. (2010). Pengaruh produk domestik bruto dan indeks pembangunan manusia. Ekonomi Pembangunan, 8(2), 357-366.

Susanto, A. B., \& Lucky, R. (2002). Pengaruh Indeks Pembangunan Manusia (IPM) dan Inflasi Terhadap Pertumbuhan Ekonomi di Kabupaten Lamongan. Jurnal Ekonomi, 5(1), 1-20. https:/ / core.ac.uk/download/pdf/230751247.pdf

Syamsuar, (03/10/2018), Siak Miliki 62 Perusahaan Penyumbang Dana CSR, Diakses Tgl. 10/01/2020, https://www.halloriau.com/read-siak-105962-2018-10-03siak-miliki-62-perusahaan-penyumbang-dana-csr.html.

Wahyuningrum, Yuniarti, Irwan Noor, Abdul Wachid, (2014), Pengaruh Program Corporate Social Responsibility (CSR)Terhadap Peningkatan Pemberdayaan Masyarakat (Studi pada Implementasi CSR PT.Amerta Indah Otsuka Desa Pacarkeling Kecamatan Kejayan Kabupaten Pasuruan), Jurnal Administrasi Publik (JAP), Vol.1 No.5, Hal 109-115, Jurusan 
Administrasi Publik, Fakultas Ilmu Administrasi, Universitas Brawijaya, Malang.

Widarjono, Agus, (2015), Analisis Multivariat Terapan dengan Program SPSS, Amos dan SmartPLS, Yogyakarta, UPP STIM YKPN.

Wihastuti, A. M. dan L. (2008). PERTUMBUHAN EKONOMI INDONESIA : Determinan dan Prospeknya. Ekonomi Dan Studi Pembangunan, 9(1), 44-55.

Yuliyanti, L. (2019). Pengaruh Good Corporate Governance Dan Pengungkapan Corporate Social Responsibility Terhadap Nilai Perusahaan. Jurnal Pendidikan Akuntansi $\quad \mathcal{E}$ Keuangan, 21. https:/ / doi.org/10.17509/jpak.v2i2.15464

Yusuf, N. C. dan Y. (2014). Pengaruh Tingkat Kemiskinan, Tingkat Pengangguran, Upah Minimum Kabupaten/Kota dan Laju Pertumbuhan Ekonomi Terhadp Indeks Pembangunan Manusia di Provinsi Riau. Ekonomi, 22(2), 1-12.

Zahara dan Eliyanora, Politeknik Universitas Andalas, (30/07/2014), Menggagas Corporate Social Responsibility (CSR) sebagai Salah Satu Mata Rantai Pembangunan Indonesia, Diakses Tgl. 10/01/2020, https:// akuntabilitasuinjkt. wordpress. com/ tag/laporan-keberlanjutan/. 